\title{
Development of professional practice through problem-based learning in human nutrition and
}

\author{
Romero-López, $\mathrm{M}^{\mathrm{a}}$ Carmen ${ }^{1 \mathrm{a}}$, Jiménez-Tejada, $\mathrm{M}^{\mathrm{a}} \mathrm{Pilar}^{1}$, and González-García, Francisco ${ }^{1}$ \\ ${ }^{1}$ Departament of Didactics of Experimental Sciences, University of Granada, Spain
}

\begin{abstract}
Although competency-based education is well established in health care education, research shows that the competencies do not always match the reality of clinical workplaces, especially in nutrition area. Student of Human Nutrition and Dietetics, have reported shortcomings in their general competencies, such as organizational skills, teamwork, knowledge to develop proposals for intervention. Were given to students a problem-based learning (PBL) activity with collaborative learning competence for to investigate their evolutions in collaborative learning and the knowledge in nutrition education. The results suggest that the PBL provided better preparation with respect to several of the competencies. The effect of PBL for the experienced students' collaborative learning and education nutrition competencies is especially promising in the professional development of future nutritionists.
\end{abstract}

Keywords: Competency-based education; problem-based learning; nutrition education; human nutrition

\section{Introduction}

The student's participation and activity are highlighted within their own learning process through the carrying out of tasks. The new educational model involves a radical change in the curriculum, in which the transformation of the methodology used in the classroom, as well as the role of the teacher, is extremely important. Although competency-based education is well established in healthcare education, research shows that the competencies do not always match the reality of clinical workplaces, especially in the area of nutrition.

Changes in this science have not only created new career opportunities, but also new professional skills, underlining the need to update the curriculum for Human Nutrition and Dietetics. In recent years, themes linked to nutrition have been gaining greater importance in curricular plans and in educational investigation regarding the knowledge students of different degrees have of these themes.

\footnotetext{
a Corresponding author: romero@ugr.es
} 
We are currently surrounded by information that is normally easy to access due to the diverse sources available. However, much of this information is unreliable or cannot be validated within a certain time. This fact means it is necessary to be able to search for relevant information when required, and to be capable of selecting (from a wide range of options), processing, addressing, interpreting and appropriating it to generate the knowledge necessary to resolve situations that arise. This is precisely what the curriculums hope to achieve: to enable students to develop extensive abilities that permit them to learn, and unlearn, throughout their lives in order to adapt to changing scenarios. The classic division between subjects or classifications of knowledge do not seem to work in the current context of education, which is why it is necessary to generate integrated knowledge [17]. The competency study improves this situation, helping to search, select, unite and combine theoretical knowledge in order to respond to situations in different contexts. The competency proposals include very different groups of knowledge, skills and character attributes that can be used to attain quality, more carefully considered learning that enables the student to generate responses and act when faced with any problem that may emerge during his/her professional development [4,5,7,10 and 13].

The main difficulty, in addition to determining the professional competencies students will need to acquire to ensure university training is optimally adapted to what is required of them as graduates, is the suitable methodology for this purpose. Possibly the most appropriate methodology would be problem-based learning (PBL) although it is not the only one. PBL teaches the student the basic competencies required for professional development based on cases similar to those the student experiences on clinical internships and in his/her future work reality [15]. This is due to psychological development, and therefore learning, being generated through guided participation in social activity with colleagues who support and stimulate understanding of the task, fostering the skills involved in the use of certain cultural artefacts, [12].

A nutrition expert should not only be a transmitter of knowledge, they should also be able to develop proposals for intervention in formal contexts (school) and non-formal contexts (museums, schools, parents associations, etc.). However, sometimes these competencies are not developed in their studies.

"Knowing how to apply the science of nutrition to the feeding and education of groups of people and individuals in health and disease" is one of the objectives of these professionals. Therefore, this study aims to evaluate the efficiency of PBL as a method for achieving an improvement in the acquisition of competencies among students of Human Nutrition and Dietetics.

The student's participation and activity are highlighted within their own learning process through the carrying out of tasks. The new educational model involves a radical change in the curriculum, in which it is very important the transformation of the methodology used in the classroom as well as the role of the teacher. Although competency-based education is well established in health care education, research shows that the competencies do not always match the reality of clinical workplaces, especially in nutrition area.

Changes in this science have not only created new career opportunities, but also new professional skills, highlighting the need to update the curricula and curricula of higher degree in Human Nutrition and Dietetics.

The "knowing how to apply the science of nutrition to the feeding and education of groups of people and individuals in health and disease." [20] is one of the objectives of these professionals.

However, not always taken into account when forming future nutritionists, being forgotten skills such as "propose, design, plan and / or performing programs for food and 
nutrition education, and develop the necessary material in any community infrastructure (schools associations, civic centers ...)"

Several results shows us, the need to design feasible and evidence-based competency frameworks that fit the workplace reality. This paper outlines a competency-based framework, designed to facilitate learning and assessment in pre graduate of Human Nutrition and Dietetics.

Nutrition expert should not be only a transmitter of knowledge, must be able to develop proposals for intervention in formal contexts (school) and informal contexts (museums, schools, parents, associations, etc.). However, these skills are often not developed in the studies and therefore, students do not see it important.

We have study the graduates' perceptions of how well their training had prepared them for general competencies and in nutrition education practice in particular. Among the 32 participants, 8 from 3rd graders while the other 24 th graders. For this study, we created some competency-based learning practical activities related to nutrition education. Each activity, highlighted between 3 and 5 competencies of nutrition education, necessary for their work, described by the Spanish Association of Nutritionists and University of Granada.

\section{Methodology}

\subsection{Sample}

The study was conducted on 32 students in their third year of a Human Nutrition and Dietetics degree.

\subsection{Activities and procedure}

The students were divided into groups of 3-5 people according to similarity criteria. These groups were maintained for the duration of the academic year. Firstly, each group was provided with a rubric that detailed the competencies they could hope to achieve with each activity and its evaluation method.

Following that, we designed some practical competency-based learning activities related to nutrition education. Each activity highlighted between three and five competencies of nutrition education that are necessary for future employment, as described by the Spanish Association of Nutritionists and the University of Granada.

The activities to be undertaken were as follows:

1) Design an educational activity to promote the consumption of fruit and vegetables among children $10-12$ years old.

2) Design a nutritional guide for adolescents.

3) Perform a didactic quality analysis of the nutritional pyramids and wheels present in different books aimed at adults.

4) Plan a brief investigation into the influence of a nutritional myth among the healthy adult population.

5) Design a nutritional information website for adults regarding the previously investigated myth.

6) Create and organise a Hospital Nutrition unit.

The activities were carried out one per month for six months. At the beginning of each month, the students performed one of the described activities using a traditional focus. 
Afterwards, they would have to present that activity to their colleagues and teacher in order to be assessed by both groups using the rubric provided. The grade of each group was the average mark that was calculated using the teacher's grade and the average of the marks given by the other students. At the end of the month, once the theoretical part was explained upon the conclusion of the corresponding activity, the students were presented with a problem related to the same activity. As before, the solution to the problem had to be presented in class and assessed using the same procedure. The value of using problems in learning processes was assessed by comparing the average mark obtained from the traditional focus activities with those obtained from PBL.

In order to find out the opinion of the students with regards to the methodology used, they were provided with an anonymous questionnaire at the end of the academic year. This questionnaire included some items validated by Vargas [21], which were modified for this study (Table 1).

\subsection{Statistical study}

By performing an ANOVA, the average marks obtained by all the students for each activity and focus using the rubrics provided were compared. As such, it will be possible to observe if there are any significant differences between the marks obtained through the traditional method and those gained using PBL. The statistical study was carried out using SPSS 15.0.; p-values of $\leq 0.05$ were considered significant.

Table 1. Items selected to find out about student opinion regarding problem-based learning (PBL).

\begin{tabular}{l}
\hline I am happy with the case method experience used on this course \\
\hline $\begin{array}{l}\text { This way of working (cooperative learning) has increased my } \\
\text { interest in the subject's content }\end{array}$ \\
\hline I would have preferred to work alone \\
\hline I believe I would have learned more by resolving the cases myself \\
\hline There were internal conflicts within the group \\
\hline This methodology motivates me to study more \\
\hline $\begin{array}{l}\text { I have learned more with this methodology than with the traditional } \\
\text { method }\end{array}$ \\
\hline $\begin{array}{l}\text { I feel better prepared for the world of work with this methodology } \\
\text { than with the traditional method }\end{array}$
\end{tabular}

\section{Results}

The average marks of the students show that initially the grades obtained for each traditional focus activity were higher than those attained through PBL, although the differences are not statistically significant, $p=0.08$. The rubrics are characterised as being an objective assessment instrument, making the variations in the final marks given by the students and teacher as minimums in the majority of cases. The students are more familiar with the traditional focus activities, obtaining higher marks with these activities at the beginning of the course than with PBL. Despite this, the scores obtained do not exceed the average mark of 6 . This is due to the use of the rubric as an objective assessment tool, enabling one to observe how the majority of the groups use a high level of theoretical content in their material activities without adapting to the specific activity demanded. This 
problem was more obvious in those activities that were based on PBL. It must be considered that this was the first time groups of students were facing this kind of activities, therefore uncertainty was generated and more effort was required. This is possibly why $15.6 \%(5 / 32$ students) are not happy with the methodology and have not had an increase in interest for the subject instigated by the methodology. It must be understood that this learning method is not usually used in the field of nutrition, despite being well established in other health disciplines $[19,9,14,18]$.

Once the students began to familiarize themselves with this type of activity, the experience became easier and the average marks obtained increased (Fig. 1). They improved their ability to detect the problems and, above all, apply theoretical knowledge learned in previous years. Finally, the average mark for traditional focus activities remained the same, while marks with a PBL approach were progressively increasing (Fig 1).

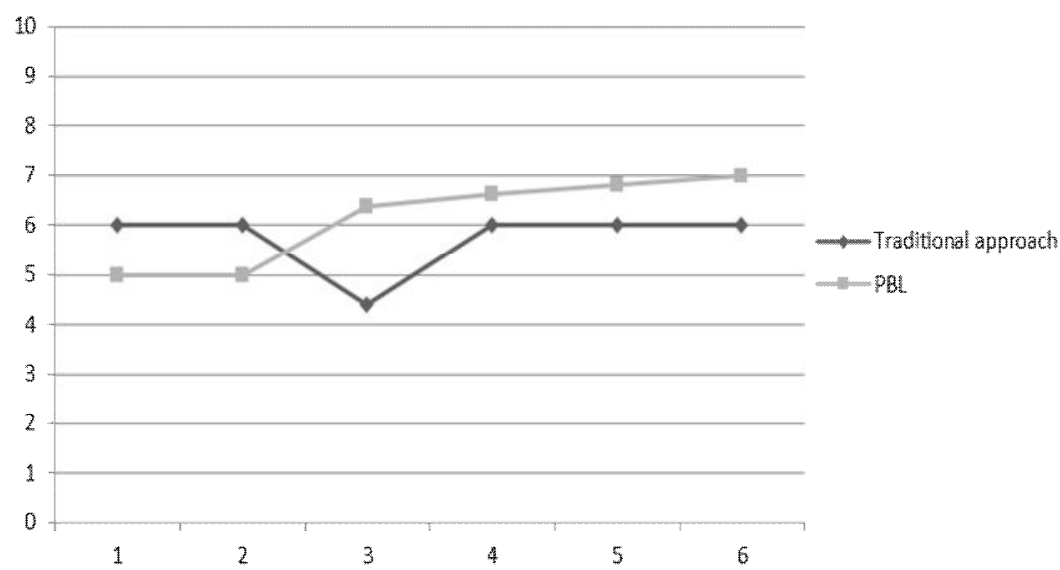

Figure 1. Grade point average before and after using the skills assessment grading for: 1) Educational activity for children, 2) Nutritional guide, 3) Analysis of the didactic quality of nutritional pyramids and wheels, 4) Investigation into the influence of a nutritional myth, 5) Nutritional information website for adults about nutritional myth, 6) Creation and organisation of a Hospital Nutrition unit.

Despite this improvement, the students continued to find difficulties with regards to using theoretical knowledge in the practical situation outlined, especially when the work was designed for a healthy population of children or adolescents. They were not capable of correctly designing an educational action in this population and usually they were using material with nutrition ideas and concepts that were too advanced.

In spite of the difficulties experienced throughout the course, $84.4 \%$ of the students (27/32 students) are happy with the experience and believe that this methodology motivates their learning for the subject. All the students agreed that, by using PBL, they learn more than by using the traditional method, and that PBL better prepares them for future work (Table 2).

Although statistically significant differences have not been found, the development of the students through the use of PBL can be noted in the present study as being more positive than with traditional methods. The ability of the student to reach judgements and conclusions improves, supporting the gathering and evaluation of information about the problem. Another benefit this methodology brings is the development in the student's ability to work in a team, as well as the technical ability in the field of nutrition. 
Table 2. Student opinions on problem-based learning.

\begin{tabular}{llll}
\hline & Unsure & Sure & Very Sure \\
\hline I am happy with the case method experience used on this course & 5 & 20 & 7 \\
\hline $\begin{array}{l}\text { This way of working (cooperative learning) has increased my interest in the } \\
\text { subject's content }\end{array}$ & 5 & 19 & 8 \\
\hline I would have preferred to work alone & 9 & 1 & 22 \\
\hline I believe I would have learned more by resolving the cases myself & 24 & 8 & 0 \\
\hline There were internal conflicts within the group & 27 & 5 & 0 \\
\hline This methodology motivates me to study more & 5 & 22 & 5 \\
\hline I have learned more with this methodology than with the traditional method & 0 & 6 & 26 \\
\hline $\begin{array}{l}\text { I feel better prepared for the world of work with this methodology than with } \\
\text { the traditional method }\end{array}$ & 0 & 2 & 30 \\
\hline
\end{tabular}

However, and despite considering that students have learned more through this method of team work $(75 \% ; 24 / 32$ students), it can be noted that the majority state that they would have preferred to work alone (71.8\%; $23 / 32$ students). This evidence, in our opinion, shows a lack of development for this competency throughout the nutritionist curriculum, therefore, the use of methodologies such as the methodology proposed in the present study should be reinforced in order to strengthen such an important competency.

We believe the didactic proposal established in the present study enables the student to tackle real and complex problems that require the development of real solutions, [8, 16]. This change is due to PBL enabling the establishment of substantive, non-arbitrary connections between the information received and prior knowledge. Furthermore, thought processes are revised and modified, establishing new connections and relations that ensure the comprehensive memorising of what has been learned [6]. As such, this provides significant learning where students acquire the competencies required to be able to carry out their professional work. This fact can be observed in the increase in the marks obtained by the students in the last PBL activities. Furthermore, capacity for communication and communication interactions improves through the exchanging of ideas with fellow students, given that together they can all contribute ideas that enable them to reach the solution to the problem presented [1].

\section{Conclusions}

It can be concluded that the effect of PBL for the experienced student's collaborative learning and educational nutrition competencies is especially promising in the professional development of future nutritionists.

Learning teamwork skills is an important developmental process for students, one that will serve them well as they embark on their lives in the workplace. By providing positive, well-planned experiences working in cooperative learning groups, teachers can help students to develop these skills.

\section{Acknowledgements}

To the investigation project HUM-613 


\section{References}

1. Álvarez, A., del Río, P., Educación y desarrollo: la teoría de Vigotsky y la zona de desarrollo próximo. En Coll C, Palacios J, Marchesi A (eds.) Desarrollo Psicológico y Educación II, Madrid: Alianza Editorial, (2000)..

2. Asociación española de dietistas-nutricionistas, Perfil de las competencias del titulado universitario en nutrición y dietética. Documento inédito, (2003).

3. Bueno, P. M., \& Fitzgerald, V. L., Aprendizaje Basado En Problemas. Theoria, 13, 145-157, (2004).

4. Canalejas Pérez, M., Martínez Martín, M., Pineda Ginés, M., Vera Cortés, M. L., Soto González, M., Martín Marino, Á., et al. , Estilos de aprendizaje en los estudiantes de enfermería. Educación médica, 8(2), 33-40, (2005).

5. Cano, E., La evaluación por competencias en la educación superior. Profesorado: revista de currículum y formación del profesorado, 12(3), 11, (2008).

6. Coll, C., Significado y sentido en el aprendizaje escolar. Reflexiones en torno al concepto de aprendizaje significativo. Infancia y Aprendizaje, 41,131-142, (1988).

7. Davó, M. C., Gil-González, D., Vives-Cases, C., Álvarez-Dardet, C., Ronda, E., OrtizMoncada, R., et al.,¿Quiénes y qué pueden hacer en salud pública? Las competencias profesionales como base para la elaboración de programas en el Espacio Europeo de Educación Superior. Gaceta Sanitaria, 23(1), 5-12, (2009).

8. Duch, B. J., Groh, S. E., \& Allen, D. E., The power of problem-based learning: a practical" how to" for teaching undergraduate courses in any discipline. Stylus Publishing, LLC., (2001).

9. Escribano, A., El aprendizaje basado en problemas: una propuesta metodológica en educación superior. Narcea Ediciones, (2008).

10. Fernández March, A. La evaluación orientada al aprendizaje en un modelo de formación por competencias en la educación universitaria. REDU. Revista de Docencia Universitaria, 8(1), 11-34, (2010).

11. García, M. E. C., La evaluación por competencias en la educación superior. Profesorado. Revista de Currículum y Formación de Profesorado, 12(3), 1-16, (2008).

12. Guitart, M. E., Del" aprendizaje basado en problemas"(ABP) al" aprendizaje basado en la acción"(ABA): claves para su complementariedad e implementación. REDU: Revista de Docencia Universitaria, 9(1), 91-107,(2011).

13. Hernández Pina, F., Rosário, P., Cuesta Sáez de Tejada, J. D., Martínez Clares, P., \& Ruiz Lara, E., Promoción del aprendizaje estratégico y competencias de aprendizaje en estudiantes de primero de universidad: evaluación de una intervención. Revista de Investigación Educativa, 24(2), 615-631, (2010).

14. Kilroy, D. A., Problem based learning. Emergency Medicine Journal, 21(4), 411-413, (2004).

15. Molina Ortiz, J. A., García González, A., Pedraz Marcos, A., \& Antón Nardiz, M. V., Aprendizaje basado en problemas: una alternativa al método tradicional. Revista de Docencia Universitaria, 3(2), 79-85,(2003).

16. Morales, P. \& Landa, V., Aprendizaje basado en problemas. Theoria, 13(1) 145-157, (2004).

17. Morin, E., Los siete saberes necesarios para la educación del futuro. Bogotá DC: Republica de Colombia, Ministerio de Educación Nacional, (2000).

18. Neville, A. J., Problem-based learning and medical education forty years on. Medical Principles and Practice, 18(1), 1-9, (2009).

19. O'neill, P. A., The role of basic sciences in a problem-based learning clinical curriculum. Medical Education, 34(8), 608-613, (2000). 
20. Universidad de Granada (2014, 10 marzo). Objetivos y competencias del grado de Nutrición Humana y Dietética. Descargado de http:/grados.ugr.es/ nutricion/pages/ titulacion/objetivos?login_form_register.

21. Vargas, C., El método del caso en la enseñanza del Derecho: experiencia piloto de un piloto novel. Revista de Formación e Innovación Educativa Universitaria. 2(4), 193 206, (2009). 